\section{Economic Factors in World Peace}

IN his Alex Wood Memorial Lecture, "The Reconciling Spirit and the Economic Order", delivered in Glasgow on February 19, and which has now been published (pp. 17. London : Fellowship of Reconciliation, 1955 ; $1 s .6 d$.), Prof. C. F. Carter analyses first the several arguments that the causes of war are primarily economic. He believes that economic factors have played only a subsidiary part in the great conflicts of this century, that we are justified in thinking that we are achieving more, and not less, willingness to consider the interests of others and that pacifists have drawn too sharp a distinction between police action and war. Economic wrong, waste and injustice still have to find their remedy; but, as Prof. Carter points out, we cannot afford to do without the great efficiency of large-scale factory production and, while the capitalist system can show examples of ruthless or dishonest profit-making, it can also show many of disinterested public service. Any other way of running our economic affairs would equally depend on much the same human beings, nor is there a simple choice between a system based on competition and one based on co-operation; both exist in any economic system. Inequality and competition between individuals result from our need for a discipline to help us give of our best in production, and such a discipline is not necessarily a bad thing. The conflict between management and labour is not necessarily to be removed by a change to public ownership but by better techniques of management -a more imaginative understanding of the other man's work and aspirations. While, therefore, we should not ascribe to a particular economic system difficulties which would be inherent in any economic system and should distrust the simple solution, Prof. Carter pleads for greater efforts to understand the position of the other man, to see the good in that and the evil in our own, and to be solid and sensible in our proposals for change. Anything we can do to increase personal knowledge about those with whom we are in an economic relationship can be a way of lessening conflict.

\section{Mount Everest Foundation}

A Mount Everess Foundation for the support of scientific work in mountain regions has recently been set up by the Royal Geographical Society and the Alpine Club with funds acquired from the proceeds of the books, film, lectures and other activities which followed the successful Everest Expedition of 1953, sponsored by the two bodies. Within the broad object of supporting the exploration of mountain regions, the Foundation will particularly aid mountaineering expeditions exploring, to some extent at least, little-known or unknown territory, but not necessarily engaged in a particular branch of scientific research ; but provision is also made, more specifically, for the support of scientific investigations in mountain country, not necessarily involving special mountaineering technique, or new exploration in a geographical sense. In this scientific field, grants may be made for research into geography, topography, geology, ethnology, meteorology, botany, zoology, entomology, glaciology, and allied studies, either in, or concerned with, mountain regions; physiological studies dealing with the effects of altitude upon the human organism, and the means of countering such effects, are also among the objects of the Foundation. Those seeking grants should write for application forms to the Honorary Secretary, Mount Everest
Foundation, c/o Alpine Club, 74 South Audley Street, London, W.1. The forms should reach the Foundation not later than February 1, April 1 and October 1 each year, for consideration in April, June and December, respectively.

\section{New Nature Reserves in Britain}

The Nature Conservancy on July 28 announced the establishment of three new nature reserves. The first of these, the Wychwood Forest Nature Reserve, covers about 647 acres of mixed woodland, about seven miles west of Woodstock. The mixed fauna and ground flora are rich, and it is intended that the reserve shall be a permanent forest, regenerating naturally and consisting of indigenous species of hardwoods on a long rotation. The reserve will be used for scientific research and will not be open to the public. The Tring Reservoirs Nature Reserve covers an area of 50 acres of the banks only of the four reservoirs, Wilstone, Marsworth, Little Tring and Startopsend, which when full have a combined water area of more than 200 acres. The marshy ground provides a habitat for plants such as the round-fruited rush (Juncus compressus), the orange foxtail (Alopecurus aequalis) and the broad-leaved ragwort (Senecio fluviatilis), which are rare in Britain; but the reservoirs are best known to naturalists as a bird sanctuary, and in 1938 were the first recorded site in Britain for the nesting of the little ringed plover. The nesting species include shoveller, teal, pochard and tufted duck, little and great crested grebe, reed warbler and sedge warbler. Permits will be necessary for those wishing to undertake research, collect specimens, or to visit parts of the reserve away from the footpaths. The Hales Wood Nature Reserve covers only twenty acres about two and a half miles from Saffron Walden, and is one of the best known examples in Britain of oak-ash woodland on chalky boulder clay where the true oxlip (Primula elatior) has replaced the primrose in the herb layer. The shrub layer consists mainly of hazel, with occasional maple, blackthorn, dogwood and the large guelder rose ; as the wood must be kept undisturbed, access permits can be granted only in very limited numbers and for special reasons.

\section{Department of Scientific and Industrial Research}

IN a written answer in the House of Commons on July 21, Mr. J. R. Bevins, Parliamentary Secretary to the Ministry of Works, as representing the Lord President of the Council, gave the names of the members of the committee which is investigating the work of the Department of Scientific and Industrial Research as follows : Sir Harry Jephcott (chairman), chairman and managing director, Glaxo Laboratories, Ltd. ; Mr. C. H. Andrew, deputy secretary, Board of Trade ; Sir Hugh Beaver, managing director, Arthur Guinness, Son and Co., Ltd. ; Mr. E. W. Playfair, third secretary, H.M. Treasury ; Sir Alexander Todd, professor of chemistry, University of Cambridge.

\section{Recent Lunar Research}

A PAPER by Dr. H. Percy Wilkins which appears in the Journal of the British Interplanetary Society $(13$, No. 6 ; November 1954) is the first of a series of papers which are to appear dealing mainly with changes in lunar topography. Dr. Wilkins returned recently from a tour of the United States where, as he describes it, "with traditional courtesy and hospitality the giant American telescopes were freely placed at my disposal ....". The instruments 